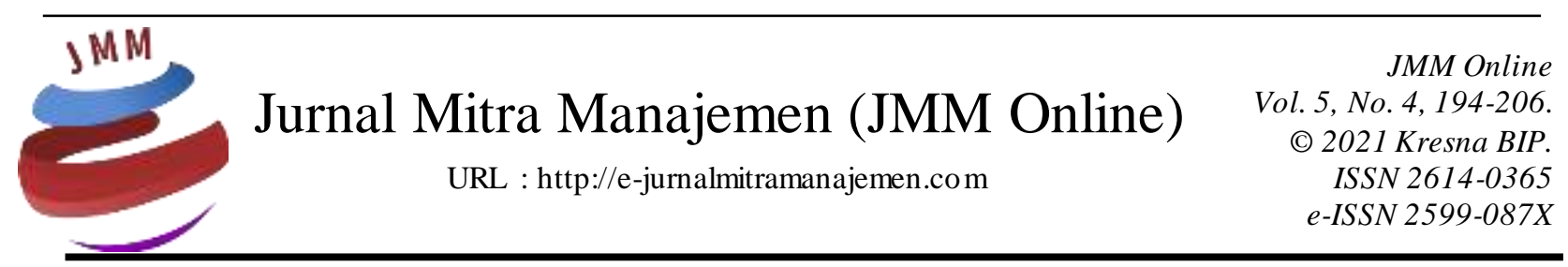

\title{
ANALISIS TINGKAT PARTISIPASI, SIKAP DAN PERILAKU, KONDISI SOSIAL EKONOMI MASYARAKAT TERHADAP PENDAPATAN PBB DI KECAMATAN BENJENG KABUPATEN GRESIK
}

\author{
Usnan 1), Wasis Budiarto ${ }^{2)}$, Indra Prasetyo ${ }^{3)}$ \\ Universitas Wijaya Putra Surabaya
}

\section{INFORMASI ARTIKEL}

Dikirim : 31 Maret 2021

Revisi pertama : 05 April 2021

Diterima :09 April 2021

Tersedia online : 06 Mei 2021

Kata Kunci: Tingkat Partisipasi, Sikap dan Perilaku, Kondisi Sosial dan Ekonomi Masyarakat, Pendapatan PBB

Email : usnan100@gmail.com

\section{ABSTRAK}

Penelitian ini bertujuan untuk mengetahui pengaruh tingkat partisipasi, sikap dan perilaku, kondisi sosial ekonomi masyarakat terhadap pendapatan PBB di Kecamatan Benjeng Kabupaten Gresik. Penelitian ini termasuk penelitian kuantitatif. Sampel diambil dengan menggunakan teknik purposive sampling berjumlah 115 responden. Data yang digunakan dalam penelitian ini adalah data primer yang diambil langsung dari petugas desa. Berdasarkan hasil penelitian yang telah dilakukan didapatkan hasil bahwa tingkat partisipasi, sikap dan perilaku, kondisi sosial ekonomi masyarakat di Kecamatan Benjeng Kabupaten Gresik termasuk dalam kategori tinggi. Tingkat partisipasi petugas Desa berpengaruh signifikan terhadap Pendapatan PBB Desa di Kecamatan Benjeng Kabupaten Gresik. Sikap dan Perilaku Petugas Pajak berpengaruh signifikan terhadap Pendapatan PBB Desa di Kecamatan Benjeng Kabupaten Gresik. Kondisi Sosial Ekonomi Masyarakat berpengaruh signifikan terhadap Pendapatan PBB Desa di Kecamatan Benjeng Kabupaten Gresik. 


\section{PENDAHULUAN \\ Latar Belakang}

Negara Indonesia sebagai negara maju memiliki pendapatan dari berbagai sumber, salah satunya yaitu berasal dari pemungutan pajak, baik pajak negara maupun pajak daerah, yang mana tidak dapat dipungkiri pajak sudah menjadi sumber terbesar pendapatan negara kita. Pajak merupakan kontribusi wajib kepada negara yang terutang oleh orang pribadi atau badan yang bersifat memaksa berdasarkan UndangUndang, dengan tidak mendapatkan imbalan secara langsung dan digunakan untuk keperluan negara bagi sebesar-besarnya kemakmuran rakyat (UU No. 28 Tahun 2007). Pajak merupakan alat bagi pemerintah dalam mencapai tujuan untuk mendapatkan penerimaan baik yang bersifat langsung maupun tidak langsung dari masyarakat guna membiayai pengeluaran rutin serta pembangunan nasional dan ekonomi masyarakat.

Salah satu bentuk pajak dalam negeri adalah Pajak Bumi dan Bangunan (PBB). PBB adalah pajak yang dipungut atas tanah dan bangunan karena adanya keuntungan atau kedudukan sosial ekonomi yang lebih baik bagi orang atau badan yang mempunyai suatu hak atasnya atau memperoleh manfaat dari padanya. Hasil penerimaan Pajak Bumi dan Bangunan, akan diarahkan untuk kepentingan masyarakat di daerah yang bersangkutan, karena itu sebagian besar alokasi pajak akan diserahkan kepada Pemerintah Daerah. Penggunan pajak sesuai kebutuhan daerah yang diharapkan akan merangsang masyarakat untuk memenuhi kewajibannya dalam membayar pajak. Pajak Bumi dan Bangunan merupakan pajak objektif atau pajak kebendaan karena besar kecilnya pengenaan pajak ditentukan oleh kondisi objek pajaknya yang berupa bumi dan bangunan. Besarnya pajak ditentukan sepenuhnya oleh kondisi objek pajak yang tercermin dalam Nilai Jual Objek Pajak (NJOP). Wajib pajak hanyalah sekedar penanggung pajak dan penentuan besarnya pajak terutang tidak terkait dengan besarnya penghasilan wajib pajak.

Kondisi ekonomi masyarakat juga sangat mempengaruhi besarnya penerimaan pajak, contohnya saja pada tahun 2010, Untuk memperbesar sumber pembiayaan negara, pemerintah berupaya meningkatkan pendapatan dari pajak, di tengah kondisi ekonomi yang belum sepenuhnya pulih dari krisis financial global, kebijakan pemerintah menaikkan pajak dinilai kurang tepat. Karena kenaikan pajak akan semakin melemahkan kemampuan ekonomi masyarakat dalam memperoleh pendapatan, dampak lainnya melemahnya daya beli masyarakat sehingga menurunkan pertumbuhan ekonomi.

Berdasarkan keadaan di atas maka ada trade off antara kenaikan pajak dan penurunan pendapatan pemerintah. Ada dua faktor yang mendasari terjadi trade off antara kenaikan pajak dan penurunan pendapatan yakni efek aritmatika dan ekonomi. Efek aritmatika menunjukkan kenaikan pendapatan negara yang semakin besar akibat kenaikan pajak yang semakin tinggi. Efek aritmatika itu akan mengalami titik jenuh lalu berbalik menjadi efek negative terhadap penerimaan negara. Sebab, kenaikan pajak akan menimbulkan efek ekonomi yang kian besar jika kenaikan pajak semakin tinggi (Razali Ritonga, 2016). Konkretnya, semakin tinggi pajak akan semakin melemahkan aktivitas ekonomi yang pada gilirannya semakin menurunkan penerimaan pemerintah. 
Sikap dan perilaku petugas PBB yang ada di Kecamatan dan Desa merupakan ujung tombak dalam penerimaan $\mathrm{PBB}$ di pedesaan. Mereka memiliki tugas menyalurkan Surat Pemberitahuan Pajak Terhutang (SPPT) dari (BPPKAD) ke masyarakat. Terkadang SPPT harus di berikan dari wajib pajak satu ke wajib pajak lain secara langsung, Setelah SPPT terdistribusikan, petugas PBB di desa kadang-kadang bersama petugas PBB di Kecamatan keliling ke tempat wajib pajak untuk mengingatkan, menagih dan mengumpulkan setoran PBB dari wajib pajak ke kas pemerintah melalui Bank yang telah ditunjuk. Pembahasan ini akan di fokuskan pada partisipasi petugas Pajak Bumi dan Bangunan di Kecamatan Benjeng Kabupaten Gresik.

Tingkat partisipasi petugas desa menjadi salah satu faktor penentu bagaimana perolehan PBB Desa dapat mencapai $100 \%$, partisipasi petugas bisa dilakukan dan diwujudkan melalui beberapa cara, seperti yang di jelaskan oleh Hanif (2011:75) mengidentifikasikan Tingkat Partisipasi Petugas Desa yaitu berpartisipasi dengan cara mengumumkan surat penagihan pajak PBB kepada masyarakat, dengan cara memberikan informasi dan edukasi kepada masyarakat, menerapkan layanan konsultasi pajak kepada masyarakat. Permasalahan selama ini, dalam penyampaian surat pajak beberapa kendala kerap dihadapi, seperti kurang adanya konsultasi antara petugas dan masyarakat, kurangnya informasi yang diberikan oleh petugas pajak, dan kurangnya partisipasi petugas dalam menindaklanjuti masyarakat yang belum melakukan pembayaran pajak.

Mengingat besarnya manfaat dari penerimaan pajak Bumi dan Bangunan dalam pembangunan, maka Kecamatan Benjeng khususnya mengharapkan adanya peningkatan penerimaan dari tahun ke tahun. Namun kenyataannya di lapangan pada saat ini penerimaan Pajak Bumi dan Bangunan di Kecamatan Benjeng masih belum mencapai target bahkan mengalami penurunan penerimaan Pajak Bumi dan Bangunan setiap tahunnya.

Berdasarkan hal tersebut dapat dibuktikan melalui data statistik perolehan Pajak Bumi dan Bangunan Kecamatan Benjeng selama tiga tahun terakhir, dikutip berdasarkan data statistik Badan Pusat Statistik Kabupaten Gresik pada tahun 2016 realisasi penerimaan PBB di Kecamatan Benjeng sebesar 97,54\%, pada tahun 2017 realisasi penerimaan $\mathrm{PBB}$ di Kecamatan Benjeng menurun menjadi 94,65\% menurun sebesar 2,89\% dari tahun sebelumnya. Data realisasi penerimaan PBB di Kecamatan Benjeng pada tahun 2018 tercatat sebesar 84,35\% yang artinya menurun sebesar 10,3\% dari tahun 2017.

Oleh karena itu, peneliti ingin mengetahui hubungan tingkat partisipasi petugas desa terhadap perolehan pendapatan PBB desa di Kecamatan Benjeng Kabupaten Gresik. Berdasarkan latar belakang penelitian yang telah diuraikan di atas, penulis tertarik untuk melakukan penelitian dengan judul "Analisis Tingkat Partisipasi, Sikap dan Perilaku, Kondisi Sosial Ekonomi Masyarakat Terhadap Pendapatan PBB di Kecamatan Benjeng Kabupaten Gresik". 


\section{Rumusan Masalah}

Berdasarkan latar belakang tersebut, maka rumusan dalam penelitian ini adalah sebagai berikut:

1. Bagaimana tingkat partisipasi, sikap dan perilaku, sosial dan ekonomi masyarakat terhadap pendapatan PBB di Kecamatan Benjeng Kabupaten Gresik ?

2. Apakah ada pengaruh tingkat partisipasi terhadap Pendapatan PBB desa di Kecamatan Benjeng Kabupaten Gresik ?

3. Apakah ada pengaruh sikap dan perilaku terhadap Pendapatan PBB desa di Kecamatan Benjeng Kabupaten Gresik ?

4. Apakah ada pengaruh sosial ekonomi masyarakat terhadap Pendapatan PBB desa di Kecamatan Benjeng Kabupaten Gresik ?

\section{Tujuan Penelitian}

Berdasarkan pada perumusan masalah tersebut diatas, maka tujuan penyusunan penelitian ini adalah untuk :

1. Untuk mendeskripsikan tingkat partisipasi, sikap dan perilaku, sosial dan ekonomi masyarakat terhadap pendapatan PBB di Kecamatan Benjeng Kabupaten Gresik

2. Untuk membuktikan dan menganalisis pengaruh tingkat partisipasi terhadap Pendapatan PBB desa di Kecamatan Benjeng Kabupaten Gresik

3. Untuk membuktikan dan menganalisis pengaruh sikap dan perilaku terhadap Pendapatan PBB desa di Kecamatan Benjeng Kabupaten Gresik.

4. Untuk membuktikan dan menganalisis pengaruh sosial ekonomi masyarakat terhadap Pendapatan PBB desa di Kecamatan Benjeng Kabupaten Gresik

\section{KAJIAN PUSTAKA}

Pajak Bumi dan Bangunan (PBB)

Berdasarkan UU No. 28 Tahun 2009, Pajak Bumi dan Bangunan adalah pajak yang bersifat kebendaan dalam arti besarnya pajak terutang ditentukan oleh keadaan objek yaitu bumi/tanah dan atau bangunan. Keberadaan subjek tidak menentukan besarnya pajak. Secara detail, pengertian bumi adalah permukaan bumi (tanah dan perairan) dan tubuh bumi yang ada di dalamnya serta laut wilayah Indonesia. Contoh: sawah, ladang, kebun, tanah, pekarangan, tambang.

Sedangkan pengertian bangunan adalah konstruksi teknik yang ditanam atau diletakan secara tetap pada tanah dan atau perairan. Contoh: rumah tempat tinggal, bangunan tempat usaha, gedung bertingkat, pusat perbelanjaan, emplasemen, pagar mewah, dermaga, taman mewah, fasilitas lain yang memberi manfaat, jalan tol, kolam renang, anjungan minyak lepas pantai. UU No. 28 Tahun 2009 Pasal 77 ayat (2) menyatakan bahwa yang termasuk dalam pengertian bangunan adalah:

1. Jalan lingkungan dalam kesatuan dengan komplek bangunan.

2. Jalan tol.

3. Kolam renang.

4. Pagar mewah.

5. Tempat olahraga.

6. Galangan kapal, dermaga.

7. Taman mewah. 
8. Tempat penampungan/kilang minyak, air dan gas, pipa pinyak fasilitas lain yang memberikan manfaat.

\section{Partisipasi}

Menurut Made Pidarta dalam Astuti (2016: 31-32), partisipasi adalah pelibatan seseorang atau beberapa orang dalam suatu kegiatan. Keterlibatan dapat berupa keterlibatan mental dan emosi serta fisik dalam menggunakan segala kemampuan yang dimilikinya (berinisiatif) dalam segala kegiatan yang dilaksanakan serta mendukung pencapaian tujuan dan tanggungjawab atas segala keterlibatan. Partisipasi dapat juga berarti bahwa kelompok mengenal masalah mereka sendiri, mengkaji pilihan mereka, membuat keputusan, dan memecahkan masalahnya. H.A.R Tilaar (2018: 287) mengungkapkan partisipasi adalah sebagai wujud dari keinginan untuk mengembangkan demokrasi melalui proses desentralisasi dimana diupayakan antara lain perlunya perencanaan dari bawah (bottom-up) dengan mengikutsertakan masyarakat dalam proses perencanaan dan pembangunan masyarakatnya.

\section{Sikap dan Perilaku}

Pengertian mengenai sikap disampaikan oleh Sarlito dan Eko (2016: 151), Sikap adalah suatu proses penilaian yang dilakukan oleh seorang individu terhadap suatu objek. Objek yang disikapi individu dapat berupa benda, manusia atau informasi. Proses penilaian seorang terhadap suatu objek dapat berupa penilaian positif dan negatif. Pengertian sikap juga diuraikan oleh Slameto (2016: 191), sikap merupakan sesuatu yang dipelajari dan menentukan bagaimana individu bereaksi terhadap situasi serta menentukan apa yang dicari oleh individu dalam hidupnya.

\section{Kondisi Sosial Ekonomi Masyarakat}

Kata sosial berasal dari kata "socious" yang artinya kawan, teman. Manusia lahir dengan kapasitas yang ia miliki kemudian memulai hidup saling berkawan dan saling membina kesetiakawanan. Karena manusia hidup bersama didalam kelompok atau hidup berkelompok dan satu sama lain saling membutuhkan maka manusia sering disebut sebagai makhluk sosial (Sumarnonugroho, 2016:3). Kata sosial adalah segala sesuatu yang berkenaan dengan masyarakat (Suharso, 2016). Konsep sosiologi manusia sering disebut dengan makhluk sosial yang artinya manusia tidak dapat hidup wajar tanpa adanya bantuan dari orang lain, sehingga arti sosial sering diartikan sebagai hal yang berkenaan dengan masyarakat (Paridjo dan Waluya, 2017: 85-86).

Gilarso (2016:15) mengatakan bahwa ilmu ekonomi berhubungan dengan usaha manusia untuk mencari nafkah dan memenuhi kebutuhan-kebutuhan hidupnya dengan sumber daya yang terbatas. P.A. Samuelson (dalam Gilarso, 2016) menyebutkan ilmu ekonomi adalah studi tentang perilaku orang dan masyarakat dalam memilih beberapa alternatif penggunaan dalam rangka memproduksi berbagai komoditi untuk kemudian menyalurkannya (baik saat ini maupun dimasa depan) kepada berbagai individu dan kelompok yang ada dalam suatu masyarakat.

Penelitian yang dilakukan oleh Poniman (2015) dalam menentukan sosial ekonomi seseorang mencakup beberapa faktor diantaranya tingkat pendidikan, jenis 
pekerjaan, tingkat pendapatan, kondisi lingkungan tempat tinggal, pemilikan kekayaan, dan partisipasi dalam aktivitas kelompok dari komunitasnya.

Sedangkan menurut Wirutomo (2016) faktor yang dapat menentukan tinggi rendahnya keadaan sosial ekonomi seseorang dalam masyarakat yaitu :

1. Tingkat Pendidikan

2. Jenis Pekerjaan

3. Tingkat Pendapatan

4. Keadaan Rumah Tangga

5. Tempat Tinggal

6. Kepemilikan Kekayaan

7. Jabatan dalam Organisasi

8. Aktivitas ekonomi

\section{METODE PENELITIAN}

\section{Jenis dan Pendekatan Penelitian}

Jenis penelitian yang digunakan dalam penelitian ini adalah penelitian kuantitatif, karena penelitian ini disajikan dengan angka-angka. Hal ini sesuai dengan pendapat (Arikunto, 2010) yang mengemukakan penelitian kuantitatif adalah pendekatan penelitian yang banyak dituntut menguakan angka, mulai dari pengumpulan data, penafsiran terhadap data tersebut, serta penampilan hasilnya.

Pendekatan penelitian ini menggunakan tipe penelitian deskriptif. Menurut Sugiyono (2016: 29) penelitian deskriptif adalah metode yang berfungsi untuk mendeskripsikan atau memberi gambaran terhadap obyek yang diteliti melalui data atau sampel yang telah terkumpul sebagaimana adanya, tanpa melakukan analisis dan membuat kesimpulan yang umum.

\section{Lokasi dan Subyek Penelitian}

Lokasi penelitian dilakukan di Desa di Kecamatan Benjeng Kabupaten Gresik. Populasi dalam penelitian ini adalah seluruh petugas di 23 desa di Kecamatan Benjeng Kabupaten Gresik. Sampel yang diambil berdasarkan teknik purposive sampilng dengan mengambil Kepala Desa, Sekretaris Desa, dan Kepala Urusan Desa di masingmasing desa. Sehingga sampel yang diambil dalam penelitian ini sebanyak 115 responden dari 23 desa dikecamatan Benjeng Kabupaten Gresik.

\section{Teknik Pengumpulan Data}

Metode pengumpulan data yang digunakan dalam penelitian ini yaitu dengan menggunakan kuesioner. Kuesioner yang diberikan merupakan lembaran pertanyaan yang mengukur variabel gaya tingkat partisipasi petugas desa dan perolehan PBB desa pada masing-masing responden.

Secara umum teknik dalam pemberian skor yang digunakan dalam kuesioner penelitian ini adalah teknik skala Likert dengan skor terendah (1) dan skor tertinggi (5). Penggunaan skala Likert menurut Sugiyono (2016:132) adalah "skala likert digunakan untuk mengukur sikap, pendapat dan persepsi seseorang atau sekelompok orang tentang fenomena sosial". 


\section{Teknik Analisis Data}

Pengujian hipotesis penelitian dilakukan dengan pendekatan structural equation modelling (SEM) yang berbasis partial least square (PLS). PLS adalah model persamaan struktural (SEM) yang berbasis komponen atau varian. Structural Equation Model (SEM) adalah salah satu bidang kajian statistik yang dapat menguji sebuah rangkaian hubungan yang relative sulit terukur secara bersamaan. Menurut Santoso (2014) SEM adalah teknik analisis multivariate yang merupakan kombinasi antara analisis faktor dan analisis regresi (korelasi), yang bertujuan untuk menguji hubungan antar variabel yang ada pada sebuat model, baik itu antar indikator dengan latennya, ataupun hubungan antar laten.

\section{HASIL PENELITIAN DAN PEMBAHASAN}

\section{Hasil Penelitian}

\section{Deskripsi Variabel Penelitian}

Hasil tabulasi tersebut diolah menghasilkan deskripsi statistik variabel penelitian, seperti yang tampak pada tabel berikut:

Tabel 1. Deskripsi Variabel Penelitian

\begin{tabular}{|c|c|c|c|}
\hline Variabel & Indikator & Rata-rata & Keterangan \\
\hline \multirow{7}{*}{$\begin{array}{l}\text { Tingkat } \\
\text { Partisipasi } \\
\text { Petugas } \\
\text { Desa }\end{array}$} & Partisipasi pasif/manipulative & 3,889 & Tinggi \\
\hline & $\begin{array}{l}\text { Partisipasi dengan cara memberikan } \\
\text { informasi }\end{array}$ & 3,733 & Tinggi \\
\hline & Partisipasi melalui konsultasi & 3,967 & Tinggi \\
\hline & Partisipasi untuk insentif materiil & 4,178 & Tinggi \\
\hline & Partisipasi fungsional & 4,011 & Tinggi \\
\hline & Partisipasi interaktif & 3,911 & Tinggi \\
\hline & Self-mobilization & 4,011 & Tinggi \\
\hline \multicolumn{2}{|c|}{ Tingkat Partisipasi Petugas Desa } & 3,96 & Tinggi \\
\hline \multirow{4}{*}{$\begin{array}{l}\text { Pendapatan } \\
\text { PBB Desa }\end{array}$} & Faktor Tersampainya SPPT & 4,400 & Sangat Tinggi \\
\hline & $\begin{array}{l}\text { Keteraturan Wajib Pajak Membayar } \\
\text { PBB }\end{array}$ & 3,989 & Tinggi \\
\hline & Isu Pajak & 3,856 & Tinggi \\
\hline & Topografi Wilayah & 3,322 & Sedang \\
\hline \multicolumn{2}{|r|}{ Pendapatan PBB Desa } & $\mathbf{3 , 8 0}$ & Tinggi \\
\hline \multirow{3}{*}{$\begin{array}{c}\text { Sikap dan } \\
\text { Perilaku } \\
\text { Petugas }\end{array}$} & $\begin{array}{l}\text { Kesabaran dalam menjelaskan } \\
\text { kepada Wajib Pajak }\end{array}$ & 4,300 & Tinggi \\
\hline & Sikap dalam Melayani & 3,878 & Tinggi \\
\hline & Sikap dalam Mengatasi Keluhan & 3,855 & Tinggi \\
\hline \multicolumn{2}{|c|}{ Sikap dan Perilaku Petugas } & 4,011 & Tinggi \\
\hline \multirow{3}{*}{$\begin{array}{c}\text { Kondisi } \\
\text { Sosial } \\
\text { Ekonomi } \\
\text { Masyarakat }\end{array}$} & Tingkat Pengetahuan Wajib Pajak & 3,700 & Tinggi \\
\hline & $\begin{array}{l}\text { Tingkat Kesadaran Dalam Membayar } \\
\text { PBB }\end{array}$ & 3,700 & Tinggi \\
\hline & Tingkat Pendapatan Wajib Pajak & 3,733 & Tinggi \\
\hline \multicolumn{2}{|c|}{ Kondisi Sosial Ekonomi Masyarakat } & 4,067 & Tinggi \\
\hline
\end{tabular}


Berdasarkan Tabel diatas, dapat diketahui bahwa pada variabel tingkat partisipasi petugas desa memiliki rata-rata sebesar 3,96 yang termasuk dalam kategori tinggi. Indikator-indikator yang digunakan dalam membangun variabel tingkat partisipasi petugas desa masing-masing termasuk dalam kategori tinggi. Sedangkan pada variabel pendapatan PBB Desa, yang memiliki indikator tertinggi adalah indikator faktor tersampainya SPPT yang termasuk dalam kategori sangat tinggi. Sedangkan indikator topografi wilayah memiliki rata-rata paling rendah yaitu sebesar 3,22 yang termasuk dalam kategori sedang.

\section{Evaluasi Measurement (Outer) Model}

Evaluasi model pengukuran dilakukan untuk menilai validitas dan reliabilitas model yang dilakukan dengan convergent validity, discriminat validity, dan composite reliability. Adapun model pengukuran untuk uji validitas dan reabilitas, koefisien determinasi model dan koefisien jalur untuk model persamaan, dapat dilihat pada gambar berikut:

\section{Gambar 1. Model Pengukuran}

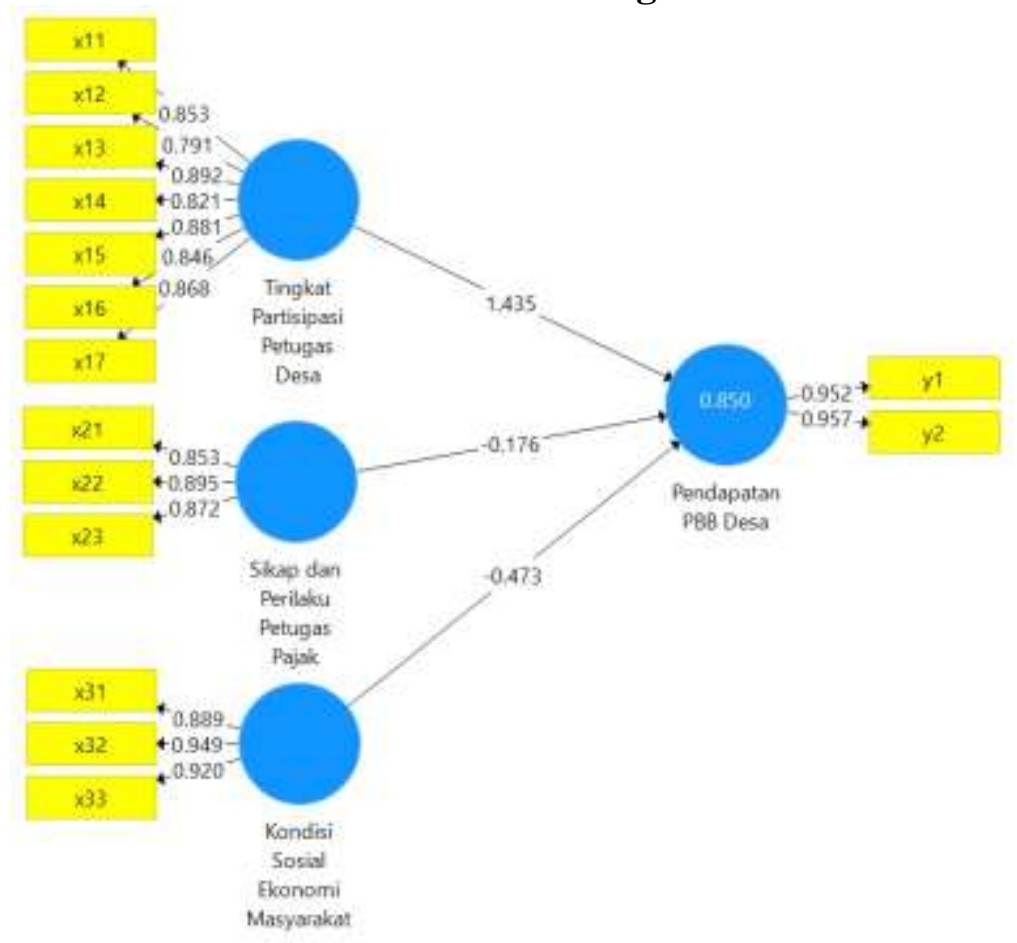

Sumber: Hasil Analisis SMARTPLS 3.0

\section{Convergent Validity}

Pada uji validitas, dilakukan evaluasi dengan tiga tahap yaitu dengan melihat outer loadings, composite reliability, dan average variance extracted (AVE). Tujuan dari uji validitas adalah untuk mengukur kesesuaian antara indikator hasil pengukuran variabel dan konsep teoritis yang menjelaskan keberadaan-keberadaan indikator dari variabel tersebut. Nilai loading factor minimum yang dapat diterima validitasnya adalah sebesar 0,6. Nilai tersebut akan menunjukkan seberapa besar korelasi antara 
indikator dengan variabel laten. Hasil loading factor untuk masing-masing indikator dapat dilihat dalam diagram jalur pada tabel berikut:

Tabel 2. Nilai Loading Factor

\begin{tabular}{|c|l|c|c|}
\hline \multirow{4}{*}{ Variabel } & \multicolumn{1}{|c|}{ Indikator } & $\begin{array}{c}\text { Loading } \\
\text { Factor }\end{array}$ & Keterangan \\
\hline \multirow{4}{*}{$\begin{array}{c}\text { Tingkat Partisipasi } \\
\text { Petugas Desa }\end{array}$} & $\begin{array}{l}\text { Partisipasi pasif/manipulatif } \\
\text { informasi }\end{array}$ & 0,853 & Valid \\
\cline { 2 - 4 } & Partisipasi melalui konsultasi & 0,791 & Valid \\
\cline { 2 - 4 } & Partisipasi untuk insentif materiil & 0,892 & Valid \\
\cline { 2 - 4 } & Partisipasi fungsional & 0,821 & Valid \\
\cline { 2 - 4 } & Partisipasi interaktif & 0,846 & Valid \\
\cline { 2 - 4 } & Self-mobilization & 0,868 & Valid \\
\hline \multirow{3}{*}{$\begin{array}{c}\text { Sikap dan Perilaku } \\
\text { Petugas Pajak }\end{array}$} & $\begin{array}{l}\text { Kesabaran dalam menjelaskan } \\
\text { kepada Wajib Pajak }\end{array}$ & 0,853 & Valid \\
\cline { 2 - 4 } & Sikap dalam Melayani & 0,895 & Valid \\
\cline { 2 - 4 } & Sikap dalam Mengatasi Keluhan & 0,872 & Valid \\
\hline \multirow{4}{*}{$\begin{array}{c}\text { Kondisi Sosial } \\
\text { Ekonomi Masyarakat }\end{array}$} & Tingkat Pengetahuan Wajib Pajak & 0,889 & Valid \\
\cline { 2 - 4 } & $\begin{array}{l}\text { Tingkat Kesadaran Dalam } \\
\text { Membayar PBB }\end{array}$ & 0,949 & Valid \\
\cline { 2 - 4 } & Tingkat Pendapatan Wajib Pajak & 0,920 & Valid \\
\hline \multirow{3}{*}{\begin{tabular}{c} 
Pendapatan PBB Desa \\
\cline { 2 - 4 }
\end{tabular}} & Faktor Tersampainya SPPT & 0,952 & Valid \\
\cline { 2 - 4 } & $\begin{array}{l}\text { Keteraturan Wajib Pajak Membayar } \\
\text { PBB }\end{array}$ & 0,957 & Valid \\
\hline
\end{tabular}

Berdasarkan Tabel diatas, diketahui nilai loading factor pada masing-masing indikator sudah melebihi nilai standar yang diperlukan $(0,6)$, sehingga tidak perlu dilakukan penghapusan indikator lagi pada model. Jika uji validitas dengan loading factor telah dipenuhi, maka model pengukuran dapat diuji lebih lanjut.

\section{Composite Reliability}

Uji selanjutnya adalah menghitung reliabilitas indikator. Tingkat reliabilitas diukur dengan nilai composite reliability dan nilai AVE. Pada composite reliability, nilai minimal yang ditetapkan untuk mengindikasikan bahwa variabel laten dapat diterima adalah sebesar 0,7. Apabila nilai composite reliability lebih besar dari 0,7, maka variabel laten dapat dikatakan reliabel. Hasil uji reliabilitas dapat dilihat pada Tabel berikut:

Tabel 3. Composite Reliability

\begin{tabular}{|c|c|c|c|}
\hline Variabel & Composite Reliability & AVE & Keterangan \\
\hline Tingkat Partisipasi Petugas Desa & 0,948 & 0,724 & Reliabel \\
\hline Sikap dan Perilaku Petugas Pajak & 0,906 & 0,906 & Reliabel \\
\hline Kondisi Sosial Ekonomi Masyarakat & 0,943 & 0,846 & Reliabel \\
\hline Pendapatan PBB Desa & 0,954 & 0,911 & Reliabel \\
\hline
\end{tabular}

Hasil uji composite reliability dari Tabel diatas menunjukkan bahwa nilai composite reliability pada masing-masing lten lebih besar dari 0,7. Hal ini menandakan bahwa laten yang diuji telah reliabel. Pengukuran lain yang juga digunakan untuk menguji reliabilitas adalah dengan menggunakan nilai AVE. 
Tujuannya adalah untuk mengukur tingkat variansi suatu komponen konstruk yang dihimpun dari indikatornya dengan menyesuaikan pada tingkat kesalahan. Nilai AVE minimal yang direkomendasikan adalah 0,5. Hasil uji dengan nilai AVE juga menunjukkan bahwa seluruh konstruk yang ada dalam model mempunyai nilai reliabilitas yang baik. Hal ini dapat dilihat dari nilai AVE pada seluruh konstruk yang memiliki nilai lebih besar dari 0,5 .

\section{Evaluasi Model Struktural (Inner Model)}

Setelah pengujian model pengukuran (outer model) langkah selanjutnya adalah melakukan pengujian pada model struktural (inner model) untuk mengetahui apakah hipotesis diterima atau ditolak. Model struktural dievaluasi dengan menggunakan $p$ value untuk mengetahui signifikansi dari koefisien parameter jalur struktural dan $R$ square untuk mengetahui pengaruh variabel laten independen terhadap variabel laten dependen.

Untuk menyimpulkan apakah hipotesis diterima atau ditolak, digunakan nilai $p$ value pada signifikansi $5 \%$ atau 0,05 . Jika pvalue $<0,05$ maka $\mathrm{H}_{0}$ ditolak, dengan kata lain terdapat pengaruh yang signifikan antar variabel tersebut. Namin jika pvalue > 0,05 maka $\mathrm{H}_{0}$ diterima artinya tidak ada pengaruh yang signifkan antar variabel. Hasil pengolahan data dapat dilihat pada Tabel berikut:

Tabel 4. Pengaruh Langsung (Direct Effect)

\begin{tabular}{|ccc|c|c|c|}
\hline \multicolumn{2}{|c|}{ Variabel Laten } & Koefisien & $\begin{array}{c}\boldsymbol{t} \text { - } \\
\text { statistics }\end{array}$ & pvalue \\
\hline $\begin{array}{c}\text { Tingkat Partsiipasi Petugas } \\
\text { Desa }\end{array}$ & $\rightarrow$ & $\begin{array}{c}\text { Pendapatan PBB } \\
\text { Desa }\end{array}$ & 1,435 & 17,455 & $0,000^{*}$ \\
\hline $\begin{array}{c}\text { Sikap dan Perilaku Petugas } \\
\text { Pajak }\end{array}$ & $\rightarrow$ & $\begin{array}{c}\text { Pendapatan PBB } \\
\text { Desa }\end{array}$ & 0,176 & 3,307 & $0,001^{*}$ \\
\hline $\begin{array}{c}\text { Tingkat Partsiipasi Petugas } \\
\text { Desa }\end{array}$ & $\rightarrow \quad \begin{array}{c}\text { Pendapatan PBB } \\
\text { Desa }\end{array}$ & 0,473 & 5,472 & $0,000^{*}$ \\
\hline
\end{tabular}

*) Signifikan dengan taraf kesalahan $5 \%(\alpha=0,05)$

Tingkat partisipasi petugas desa memiliki tingkat signifikansi sebesar 0,000 $(\mathrm{p}<0,05)$. Hal ini menunjukkan bahwa tingkat partisipasi petugas desa secara langsung berpengaruh signifikan terhadap pendapatan PBB Desa. Nilai koefisien yang diperoleh sebesar 0,792, yang menunjukkan bahwa setiap kenaikan rata-rata tingkat partisipasi petugas desa maka rata-rata nilai pendapatan PBB desa akan naik sebesar 0,792. Hal ini menunjukkan bahwa tingkat partisipasi petugas desa berpengaruh positif terhadap pendapatan $\mathrm{PBB}$ desa, semakin tinggi tingkat partisipasi petugas desa maka semakin tinggi pula pendapatan PBB desa.

\section{Koefisien Determinasi}

Nilai koefisien determinasi yang dilihat berdasarkan nilai adjusted $R$-Square digunakan untuk mengetahui seberapa besar pengaruh variabel eksogen terhadap veriabel endogen. Nilai adjusted $R$-square ditampilkan dalam Tabel sebagai berikut: 
Tabel 5. Koefisien Determinasi

\begin{tabular}{|c|c|c|}
\hline Variabel Laten Endogen & $\boldsymbol{R}$-square & Adjusted $\boldsymbol{R}$ Square \\
\hline Pendapatan PBB Desa & 0,850 & 0,844 \\
\hline
\end{tabular}

Nilai adjusted $R$ Square pada pendapatan PBB Desa diketahui sebesar 0,844. Hal ini menunjukkan bahwa pendapatan PBB Desa dapat dijelaskan oleh tingkat partisipasi petugas desa, sikap dan perilaku petugas pajak, dan kondisi sosial ekonomi masyarakat sebesar $84,4 \%$, dan $15,6 \%$ lainnya dijelaskan oleh variabel lain diluar penelitian.

\section{Pembahasan}

Hasil penelitian pengaruh tingkat partisipasi petugas desa terhadap pendapatan PBB Desa di di Kecamatan Benjeng Kabupaten Gresik menunjukkan adanya pengaruh positif dan signifikan. Hal ini ditunjukkan dengan nilai signifikansi sebesar 0,000 $(\mathrm{p}<0,000)$ dengan nilai koefisien sebesar 1,435. Semakin tinggi tingkat partisipasi petugas desa maka akan meningkatkan pendapatan PBB Desa.

Berdasarkan loading factor yang paling tinggi, indikator pada variabel tingkat partisipasi petugas desa yang paling dominan adalah indikator Partisipasi melalui konsultasi. Kerja sama antara pemerintah desa dengan aparat terkait dapat membantu dalam penyampaian pembinaan dan pengertian masyarakat akan pentingnya membayar pajak bumi dan bangunan. Dalam penagihan pajak sangsi hukum bagi wajib pajak yang tidak membayar pajak memang belum diterapkan, tapi konsekuensinya bagi masyarakat sebagi wajib pajak yaitu tidak bisa mengurus KTP, KK, ataupun yang berurusan dengan pemerintah desa tanpa menunjukkan bukti pembayaran lunas PBB kepada aparat pelaksana. Tugas pemerintah desa sebagai aparat pengelola pajak dapat benar-benar memberikan motivasi, mensosialisasi, pembinaan, penyuluhan bahwa betapa pentingnya pajak itu bagi negara untuk kepentingan rakyat dan pembangunan daerah baik infrastruktur dan suprastruktur. Sangat jelas bahwa peran pemerintah sebagai aparat pajak sangat diperlukan guna mencapai tujuan program khususnya dalam hal pajak bumi dan bangunan agar terealisasi $100 \%$ pemasukan pajak pada desa.

Hasil penelitian pengaruh sikap dan perilaku petugas pajak terhadap pendapatan PBB Desa di di Kecamatan Benjeng Kabupaten Gresik menunjukkan adanya pengaruh positif dan signifikan. Hal ini ditunjukkan dengan nilai signifikansi sebesar 0,001 $(\mathrm{p}<0,000)$ dengan nilai koefisien sebesar 0,176. Semakin tinggi sikap dan perilaku petugas pajak maka akan meningkatkan pendapatan PBB Desa.

Hasil ini sejalan dengan hasil penelitian yang telah dilakukan oleh Binambuni (2013) yang menyatakan bahwa pelayanan pajak berpengaruh terhadap kepatuhan wajib pajak. Hal ini akan meningkatkan pendapatan Pajak desa. Sedangkan hasil penelitian ini tidak sejalan dengan penelitian yang dilakukan oleh Winerungan (2013) menyatakan bahwa pelayanan pajak tidak berpengaruh terhadap kepatuhan wajib pajak.

Hasil penelitian pengaruh kondisi sosial ekonomi masyarakat terhadap pendapatan PBB Desa di di Kecamatan Benjeng Kabupaten Gresik menunjukkan adanya pengaruh positif dan signifikan. Hal ini ditunjukkan dengan nilai signifikansi sebesar 0,000 $(\mathrm{p}<0,000)$ dengan nilai koefisien sebesar 0,473. Semakin tinggi kondisi sosial ekonomi masyarakat maka akan meningkatkan pendapatan PBB Desa. 
Kontribusi masyarakat bagi perkembangan dan pertumbuhan ekonomi di Indonesia salah satunya dengan memberikan kontribusi berupa pembayaran pajak kepada negara. Wajib pajak dapat melakukan pembayaran pajak tersebut pastinya dengan menyisihkan sebagian pendapatan yang diperolehnya. Apabila wajib pajak mempunyai pendapatan yang cukup, maka individu tersebut mampu untuk memenuhi kebutuhan hidup dan kewajibannya sebagai warga negara yang baik yaitu dengan membayar pajak tepat pada waktunya. Dengan demikian, semakin baik tingkat ekonomi wajib pajak maka niat untuk berperilaku patuh membayar PBB akan semakin tinggi.

\section{KESIMPULAN DAN SARAN \\ Kesimpulan} berikut:

Kesimpulan yang diperoleh berdasarkan hasil penelitian ini adalah sebagai

1. Tingkat partisipasi, sikap dan perilaku, dan kondisi sosial dan ekonomi masyarakat di Kecamatan Benjeng Kabupaten Gresik termasuk dalam kategori tinggi.

2. Tingkat partisipasi petugas Desa berpengaruh signifikan terhadap Pendapatan PBB Desa di Kecamatan Benjeng Kabupaten Gresik.

3. Sikap dan Perilaku Petugas Pajak berpengaruh signifikan terhadap Pendapatan PBB Desa di Kecamatan Benjeng Kabupaten Gresik.

4. Kondisi Sosial Ekonomi Masyarakat berpengaruh signifikan terhadap Pendapatan PBB Desa di Kecamatan Benjeng Kabupaten Gresik.

\section{Saran}

Dalam penyelenggaraan penarikan pajak bumi dan bangunan pada masyarakat perlu adanya peningkatan dan harus adanya ketegasan dalam hal tersebut. Walaupun itu tetangga sendiri atau kerabat. Karena itu sudah menjadi kewajiban seluruh perangkat desa bukan hanya bagian penarikan pajak saja, tetapi kepekaan dari perangkat itu sendiri.

\section{DAFTAR PUSTAKA}

Arikunto, S. 2010. Prosedur Penelitian Suatu Pendekatan Praktik. Jakarta: Rineka Cipta.

Astuti, Dwiningrum, Siti, Irene. 2011. Desentralisasi dan Partisipasi Masyrakat Dalam Membayar Pendidikan, Yogyakarta: Perpustakaan Pelajaran

Binambuni, donny. 2013. Sosialisasi PBB Pengaruhnya Terhadap Kepatuhan wajib Pajak di Desa Karatung Kecamatan Nanusa Kabupaten Talaud. Jurnal EMBA. Vol.1 No.4 ISSN: 2078-2087

Gilarso. 2016. Ilmu Ekonomi Mikro. Teori Permintaan. PT.Angkasa Bhakti. Semarang H.A.R. Tilaar. 2018. Membenahi Pendidikan Nasional. Jakarta: PT. Rineka Cipta

Hanif Nurcholis, 2011. Pertumbuhan dan Penyelenggaraan Pemerintahan Desa. Jakarta : Penerbit ERLANGGA

Paridjo dan Waluya, St. Budi. 2017. Analysis Mathematical Communication Skills Students In The Matter Algebra Based Nctm. IOSR Journal of Mathematics 13(1): 60-66. 
Poniman. 2015. Sosial Ekonomi Keluarga dan Hubungannya dengan Prestasi Belajar Anak di SMK Telkom Sandhy Putra Medan. Skripsi diterbitkan. Medan: Universitas Sumatra Utara.

Razali Ritonga. 2016. Pajak dan Pertumbuhan Ekonomi, Kompas 17 Oktober 2009, Jakarta.

Santoso, Singgih. 2014. Konsep Dasar dan Aplikasi SEM dengan AMOS 22. Jakarta: Kompas Gramedia

Sarlito, Sarwono, W \& Eko, A. Meinarno. 2016. Psikologi Sosial. Jakarta: Salemba Humanika.

Slameto. 2016. Belajar dan Faktor-Faktor yang Mempengaruhinya. Cetakan Keenam. Jakarta: PT Rineka Cipta.

Sugiyono. 2016. Metode Penelitian Kuantitatif, Kualitatif dan R\&D. Bandung: PT Alfabet.

Suharso, Ana Retnoningsih. 2016. Kamus Besar Bahasa Indonesia Edisi Lux Cetakan Kesebelas, Semarang: Widya Karya.

Sumarnonugroho, T. 2016. Sistem Intervensi Kesejahteraan Sosial. Yogyakarta.: Hanindita

Undang-Undang No. 28 Tahun 2007 Tentang Ketentuan Umum Dan Tata Cara Perpajakan (KUP)

Undang-Undang Nomor 28 Tahun 2009 tentang Ketentuan Umum dan Tata Cara Perpajakan

Winerungan, Oktaviane Lidya. 2013. Sosialisasi Perpajakan, Pelayanan Fiskus dan Sanksi Perpajakan terhadap Kepatuhan WPOP di KPP Manado dan KPP Bitung. Jurnal EMBA Vol.1 No.3 September (2013).

Wirutomo, Paulus, DKK. 2016. Sistem Sosial Indonesia. Jakarta: Universitas Indonesia (UI-Press). 